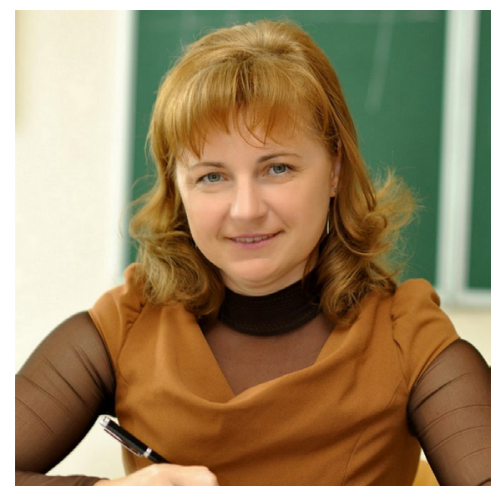

\section{Руслана Романишин,}

кандидат педагогічних наук, доцент кафедри

фахових методик і технологій початкової освіти, ДВНЗ «Прикарпатський національний університет імені Василя Стефаника»

(м. Івано-Франківськ, Україна)

\author{
Ruslana Romanyshyn, \\ $\mathrm{PhD}$ in Education, Associate Professor, \\ Department of Specialist Methods and Technologiesof \\ Elementary Education, \\ Vasyl Stefanyk Prekarpation National University \\ (Ivano-Frankivsk, Ukraine) \\ ruslana.romanyshyn@pu.if.ua \\ ORCID ID 0000-0001-8480-2702
}

УдК 373.3:37.016:511-028.31:159.922.6

\title{
НЕЙРОПСИХОЛОГІЧНІ ОСНОВИ ОБЧИСЛЮВАЛЬНОЇ ДІЯЛЬНОСТІ УЧНЯ ПОЧАТКОВОЇ ШКОЛИ: ТЕОРЕТИЧНИЙ АСПЕКТ
}

Анотація. У статті розглядається обчислювальна діяльність учнів початкової школи з точки зору нейропсихологічних досліджень. На їх основі обчислювальну діяльність віднесено до вищих психічних функцій, які притаманні тільки людині та формуються упродовж життя. Встановлено закономірності побудови процесу формування та засвоєння знань і навичок в учнів початкової школи. Цей процес забезпечується завдяки роботі кори великих півкуль головного мозку. Обчислення, як будь-яка вища психічна функція забезпечується інтегративною діяльністю всього мозку. Значення кожної ділянки мозку на якість обчислювальної діяльності можна оцінити лише з точки зору нейронауки. Вивчення локальних уражень мозку дають можливість встановити різні порушення розумових процесів, обумовлених випаданням певних компонентів психічної діяльності.

Оскільки обчислювальна діяльність, як і будь-яка діяльність є цілісним процесом, то при його розпаді ця цілісність заміщується окремностями та фрагментами. У цьому випадку діяльність порушується не тільки як ланцюг дій, але як ієрархізована система. При враженні окремих ділянок мозку обчислювальні операції розпадаються за законами своєї змістової будови.

Обчислювальні операції є складними психологічними процесами за ґенезою, структурою та протіканням, а тому зазнають найбільших труднощів при навчанні дітей у школі.

Ключові слова: обчислювальна діяльність, учні початкової школи, вищі психічні функції, процес формування обчислювальних знань і навичок, система зон мозку, які забезпечують обчислювальну діяльність.

\section{NEUROPSYCHOLOGICAL BASES OF COMPUTATIONAL ACTIVITY OF THE ELEMENTARY SCHOOL LEARNER: THEORETICAL ASPECTS}

Abstract. The article deals with the computational activity of elementary school students from the point of view of neuropsychological studies. On their basis, computational activity is attributed to higher mental functions that are inherent only to man and are formed throughout life. The regularities of constructing the process of formation and mastering of knowledge and skills in elementary school students are established. This process is ensured by the work of the cortex of the cerebral hemispheres. The computation, like any higher mental function, is provided by the integrative activity of the entire brain. The value of each part of the brain to the quality of the computational activity can be estimated only from the point of view of neuroscience. The study of local lesions of the brain makes it possible to establish various disorders of mental processes, due to the fallout of certain components of mental activity.

Since computational activity, like any other activity, is an integral process, then, when it decays, this integrity is replaced by singularities and fragments. In this case, the activity is violated not only as a chain of actions, but as a hierarchical system. With the impact of individual sections of the brain, computational operations break down according to the laws of its content structure.

The research in the field of neuroscience proves that in the case of damage to various parts of the cerebral cortex, only centers of distortion can be established, and not centers of functioning, since a complicated intellectual function cannot be localized in a particular center.

It was found that the computation is performed by the joint work of the occipital, parietal and frontal systems of the brain that we will call the system of brain regions that provide computational activity. Moreover, the functional value of a certain area of the cerebral cortex is uneven at different stages of the development of the individual, which is confirmed 
by the fundamental principle of the dynamic localization of higher mental functions. The essence of this principle is that working units of different zones and levels of the brain, providing a particular mental function may vary in the process of its formation. That is, the function changes in its structure with the development of a person. It also changes in relations with other mental processes, and, consequently, its localization varies, which differs sharply between the child and the adult. Computational operations are complex psychological processes of genesis, structure and flow, and therefore experience the greatest difficulty in teaching children in school.

Keywords: computational activity, elementary school pupils, higher mental functions, the process of computing knowledge and skills formation, the system of brain regions that provide computational activity.

\section{ВСТУП}

Постановка проблеми. Для повсякденного життя сучасній людині потрібний комплекс компетентностей, що забезпечить успішне функціонування у швидкозмінному суспільстві. Його базисом є уміння та навички. Обчислювальна компетентність, обчислювальна навичка визнані світовою спільнотою в якості ключових, оскільки сучасній людині щодня доводиться багаторазово здійснювати усні обчислення та аналізувати й оцінювати результати лічби, знаходити більш раціональний спосіб міркування.

Розглядаючи процес обчислювальної діяльності молодших школярів, слід опиратися не тільки на положення загальної психології щодо закономірностей психічного розвитку дитини, а ще й на нейропсихологічні аспекти цього процесу, оскільки, за визначенням С. Рубінштейна, психологічне і фізіологічне - це одна й та ж відображувальна дійсність реальності (Рубинштейн С. Л., 2002, с. 33).

Із психологічної точки зору обчислювальна діяльність розглядається вченими як окремий прояв психічної діяльності індивіда і описується з допомогою поняття «психічні функції», які являють собою форми психічної діяльності (Юнг К. Г., 2008, с. 202). Серед психічних функцій виділяють ті, які стосуються форм та видів пізнавальних процесів, що притаманні тільки людині - це вищі психічні функції (ВПФ), до них у психології відносять мислення, сприйняття, пам'ять, увагу, уяву, мовлення. ВПФ не є вродженими, вони формуються впродовж усього життя людини за допомогою механізму інтеріоризації.

Аналіз останніх досліджень і публікацій. Формування обчислювальних умінь та навичок пов'язується вченими Л. Виготським, О. Лурією, О. Леонтьєвим, А. Запорожцем, Д. Єльконіним, П. Гальперіним із розвитком ВПФ. Водночас Л. Виготський розглядає лічбу та обчислення як оволодіння зовнішніми засобами культурного розвитку та мислення (Выготский Л. С., 1983, с. 24). У нашому досліджені вслід за Л. Виготським та Л. Цвєтковою відносимо обчислювальну діяльність до ВПФ.

У роботах психологів Ж. Піаже (Пиаже Ж., 1969), П. Гальперіна (Гальперин П. Я., 2002), Н. Менчинської (Менчинская Н. А., 2004), В. Давидова (Давыдов В. В., 2003), Н. Непомнящої (Непомнящая Н. И., 2001) представлено складний процес формування поняття числа та обчислювальних операцій в онтогенезі. Цей процес на перших етапах розвитку дитини має наочно-дієвий характер і зводиться до перераховування елементів у зовнішньому просторовому полі. Потім обчислювальна діяльність набуває мовного характеру, а на наступному етапі формування ця функція здійснюється в ідеальному плані. Мовлення виступає, з одного боку, як засіб вираження складної системи знання, а з іншого, - як організатор діяльності з обчислення. Поступово операції, що протікають «у думці», згортаються і замінюються абстрактним арифметичним мисленням (Лурия А. Р.).

МЕТА І ЗАВДАННЯ ДОСЛІДЖЕННЯ - встановлення на основі нейропсихологічних досліджень системи зон мозку, які впливають на якість обчислювальної діяльності учнів початкової школи.

МЕТОДИ ДОслІДЖЕНнЯ: теоретичні - аналіз, систематизація та узагальнення науково-методичної літератури для розкриття основних аспектів нейропсихологічних особливостей обчислювальної діяльності учнів початкової школи.

\section{РЕЗУЛЬТАТИ ДОСЛІДЖЕННЯ}

Особливістю людського мозку є наявність у його структурі вищих відділів - кори великих півкуль, які Л. Цвєткова називає органом прижиттєвого формування нових знань та умінь (Цветкова Л. С., Семенович А.В., Котягина С.Н., Гришина Е.Г., \&Гогберашвили Т.Ю., 2006, с. 40). Саме кора головного мозку робить людину людиною і бере участь в абстрактному мисленні (Медіна Джон, 2017, с.187), а загальним механізмом мислення, як вважав О. Лурія, є аналітико-синтетична робота великих півкуль головного мозку.

Будь-яка вища психічна функція, у тому числі й обчислення, забезпечується інтегративною діяльністю всього мозку. У процесі розвитку дитини та в результаті виконання нею вправ змінюється функціональна структура процесу, і формування діяльності на наступних етапах може опиратися на вже іншу систему спільно працюючих зон (Лурия А. Р., 2003, с. 78). Незадіяні зони мозку будуть відставати у своєму розвитку, що може відбитися на якості розвитку ВПФ (Цветкова Л. С., Семенович А.В., Котягина С.Н., Гришина Е.Г., \&Гогберашвили Т.Ю., 2006, с. 65-66).

Значення кожної ділянки мозку щодо якості обчислювальної діяльності можна оцінити 3 точки зору нейрофізіологічних досліджень, які стосуються вивчення локальних уражень мозку. Такі дослідження дають можливість встановити різні порушення розумових процесів, обумовлених випаданням певних компонентів психічної діяльності, викликаних локальними пошкодженнями (Цветкова Л. С., 1997, с. 19).

Нейрофізіологічні дослідження дають можливість зрозуміти закономірності побудови процесу формування та засвоєння знань і навичок у дітей як здорових, так і з аномальним розвитком та вивчити внутрішні механізми навчання як у нормі, так і при патології психічних процесів (Цветкова Л. С., 1997, с. 5). 
За визначенням І. Павлова, нейропсихологічний метод аналізу порушених психічних процесів дозволяє з великою точністю розкласти злиті психічні процеси, які протікають у нормальних умовах, на складові частини і знайти принцип їх взаємодії (Цветкова Л. С., 200, с. 6). Такий підхід, на думку Л. Цвєткової, дає можливість зрозуміти складну ґенезу та структуру обчислювальних дій / операцій, усвідомити їх значущість, запобігти помилкам при методичних розробках і, як результат, - уникнути труднощів при засвоєнні знань та формуванні навичок (Цветкова Л. С., 1997).

Важливою закономірністю, відкритою нейропсихологією, є положення про те, що вища психічна функція не розпадається, а виникає її дезінтеграція (Цветкова Л. С., 1997, с. 5). Локальні ураження мозку не приводять до прямого «випадання» тієї чи іншої психічної функції. Патологічний осередок, що виникає в результаті пошкодження, порушує нормальну роботу певної зони мозку, яка входить до функціональної системи, і призводить до такої перебудови збережених відділів мозку, завдяки якій стає можливим новий спосіб виконання порушеної функції (Лурия А. Р., 2003, с. 130).

Як бачимо, обчислювальні операції $€$ складними психологічними процесами за генезисом, структурою і протіканням, а тому викликають найбільше труднощів при навчанні дітей у школі. При ураженнях мозку та при симптомах його недорозвинення або затримки дозрівання відповідних зон цей вид інтелектуальної діяльності порушується найбільш часто (Цветкова Л. С., 1997, с. 19).

Ураження певних зон головного мозку можуть суттєво впливати на якість обчислювальної діяльності або унеможливлюють її взагалі. Так, локалізоване ушкодження тім'яно-потиличної області лівої півкулі (нижньотім'яної) призводить до порушення просторового сприйняття, утруднення в аналізі не тільки наочних, але й символічних відношень, розпаду сприйняття символічних знаків (цифри, знаки арифметичних дій), та у розпаді обчислювальних операцій. Обчислювальні операції на ранніх етапах засвоєння мають розгорнутий характер і пізніше перетворюються в дії, що опираються на внутрішні просторові схеми. До числа таких операцій відносяться обчислення з багатоцифровими числами, де значення кожної цифри визначається ії̈ місцем (розрядом) у комплексі цифр, виконання яких можливе лише за умови збереження в оперативній пам'яті числових схем » (Лурия А. Р., 2003, с. 168).

Порушення тім'яно-потиличної області лівої півкулі проявляється у неможливості здійснювати віднімання з переходом через десяток, плутаючи при цьому напрямок виконання операцій. Так, при відніманні $31-7$ правильно виконується тільки перший етап - від 30 віднімають 7 і отримують 23, але потім не знають, чи додавати до одержаного результату одиницю, чи віднімати. Труднощі виникають і з називанням результату «22» чи «24»» (Лурия А. Р., 2003, с. 85).

Віднімання двоцифрових чисел з переходом через десяток (51 - 17) ще складніше за своєю структурою, оскільки передбачає подвійний перехід через десяток і утримання в оперативній пам'яті подвійної системи елементів. Саме ці операції порушуються при ураженні тім'яно-потиличних відділів лівої півкулі.

У випадках відносно легких уражень подібні порушення виступають в більш складних процесах: у відніманні двоцифрового числа від двоцифрового або при відніманні одноцифрового числа від двоцифрового, що вимагає переходу через десяток з проміжним розкладанням зменшуваного на складові частини, і т. ін.

Характерною особливістю при ураженнях у цій частині мозку є те, що у всіх випадках цілеспрямований характер обчислювальної діяльності залишається збереженим. Основне завдання і загальний план її виконання не порушуються, а розпадається тільки виконавча частина обчислювальної операції » (Лурия А. Р., 2003, с. 169).

Натомість навіть масивні ураження тім'яно-потиличної області правої півкулі не призводять до порушень вищих (символічних) форм пізнавальних процесів: розуміння складних логіко-граматичних структур і процеси обчислень залишаються в цих випадках абсолютно збереженими [5, с. 213].

Ураження частин потиличної зони призводять до порушення розуміння розрядного складу числа та помилок при виконанні обчислювальних операцій. В окремих випадках унеможливлюються навіть операції в межах десятка, які можуть виконуватися лише шляхом прилічування по одиниці за допомогою пальців. В інших випадках обчислювальні операції в межах десятка можуть зберігатися, проте їх виконання протікає уповільнено і спирається на інші, більш наочні засоби. Здійснення обчислювальних операцій з переходом через розряд при таких ураженнях майже неможливе. При виконанні письмового додавання може випускатися та ланка, яка відповідає за перенесення з розряду в розряд. Усні обчислення додавання двоцифрових чисел з переходом через розряд виконуються тяжко, оскільки неможливим видається аналіз розрядного складу числа. Властиві також дефекти просторової орієнтації в обчисленнях. Учні роблять помилки такого типу: $31-7=22$ (30 - $7=23$, однак замість додавання одиниці вони її віднімають). Зберігаються стереотипні дії табличного множення, хоча дії позатабличного множення порушені. Утруднені операції ділення й операції з дробами, які вимагають досить складної системи проміжних ланок і передбачене здійснення всієї системи математичних дій у думці. Порушення в обчислювальних операціях при тім'яно-потиличних ураженнях мозку проявляються і в розпаді операцій, пов'язаних з усвідомленням математичних знаків. Досить запропонувати приклади, в яких є всі операції, але пропущені математичні знаки, щоб побачити, що такі завдання є досить важкими для виконання.

При ураженні ті'яно-потиличних відділів мозку порушується і просторове сприйняття, від чого страждають складні форми процесу запам'ятовування і мовної діяльності, механізм вибору та виконання дій / операцій, погіршується виконавча сторона діяльності. Діяльність як цілісний процес і як система тут не порушується, але переходить на інший рівень організації та реалізації (Цветкова Л. С., 1995). 
Порушення в нижньотім'яній і тім'яно-потиличній частині мозку істотно впливають на якість обчислювальної діяльності в цілому.

Нейропсихологічні дослідження (П. Анохін, О. Бернштейн, Є. Грішина, Т. Гогберашвілі, І. Павлов, А. Семенович, С. Котягіна, Л. Цвєткова) показують, що уявлення про локалізацію обчислювальних операцій в нижньотім'яному «центрі» $€$ хибним. Вони свідчать про те, що складна розрядна будова числа й обчислювальні операції страждають внаслідок порушень тих складних форм просторового аналізу і синтезу, які становлять одну з важливих психофізіологічних умов для формування багатьох психічних функцій, у тому числі й обчислювальних операцій (Лурия А. Р., 2003).

Пошкодження у скронево-тім'яно-потиличній зоні спричинює затримку формування і розвиток всіх психічних функцій, які входять в структуру обчислювальної діяльності (Цветкова Л. С., Семенович А.В., Котягина С.Н., Гришина Е.Г., \&Гогберашвили Т.Ю., 2006, с. 75). Порушення лівої скроневої частини призводить до погіршення або втрати слухомовної пам'яті та впливає на сприйняття й розуміння обчислювальних операцій (Лурия А. Р., 2003, с. 156).

Ураження лобних частин мозку призводить до порушень у процесі виконання обчислень, які потребують постійного перемикання з однієї операції на іншу та мислення загалом. Виконання завдання зводиться до заміни цілісних операцій фрагментарними діями. Віднімання виду 93 - 7 супроводжується наступними ізольованими діями, які не включені в цілісний процес: $7=3+4 ; 93-3=90$; перехід через десяток з прямим перенесенням залишеного компонента $80+4=84$.

Серед інших помилок при ураженні лобних частин мозку спостерігається інерція стереотипу, завдяки чому послідовне віднімання одного і того ж числа перетворюється в повторення однотипних кінцевих чисел (100 - $7=93$ ... 83 ... 73 ... 63 і т. ін.), причому відсутнє розуміння того, що це помилка.

Для виконання будь-якого обчислення необхідно попередньо проаналізувати елементи умови, скласти певний план (стратегію) вирішення завдання, виконати відповідні цьому стратегічному плану операції і перевірити правильність одержаного результату. Саме цей процес складання і виконання програми порушується в цьому випадку. При ураженні лобних частин мозку страждає не первинна основа пам'яті, а складна мнестична діяльність у цілому (Лурия А. Р., 2003, с. 213). О. Леонтьєв писав, що діяльність як цілісний процес складається не 3 окремішностей, а з ланцюга дій, який розпадається і заміщується окремішностями та її фрагментами. У цьому випадку діяльність порушується не тільки як ланцюг дій, але як ієрархізована система (Цветкова Л. С., 1995).

У результаті аналізу проведених досліджень О. Лурія доходить висновку, що при враженні окремих ділянок мозку обчислювальні операції розпадаються за законами своєї змістової будови (Лурия А. Р.).

Однак С. Рубінштейн зазначив, що при ураженні різних ділянок кори головного мозку можна встановити лише центри порушень, а не центри функціонування. 3 того, що ураження певного поля призводить до порушення певної функції, випливає, що воно відіграє істотну роль у виконанні даної функції, але це зовсім не означає, що воно є «центром», який забезпечує цю функцію і що в ній не беруть участь інші поля. Вчений радить розрізняти локалізацію патологічного симптому у певному полі і локалізацію функції в певному «центрі» (Рубинштейн С. Л., 2002, с. 143).

Вчені-нейропсихологи (О. Лурія, К. Монаков) вважають, що складну інтелектуальну функцію неможливо локалізувати в певному центрі. Для ї̈ виконання повинні бути задіяні різні частини на обширній території мозку, діяльність яких об'єднується в одній тимчасовій структурі.

Все це уможливлює висновок, що у складні психічні функції у людини залучено велику частину кори або вся кора (весь мозок як єдине ціле). Кожна його частина залучена в цілісний процес специфічним чином. Для складних інтелектуальних функцій не існує «центрів», які б їх продукували, але в здійсненні кожної з них певні ділянки мозку відіграють особливо істотну роль. Для інтелектуальної діяльності особливо важливе значення мають частки третьої лобової звивини, нижньої тім'яної і частково скроневої, оскільки їх ураження викликає найбільш серйозні порушення вищих психічних функцій (Рубинштейн С. Л., 2002).

Оскільки при обчислювальній діяльності задіяні різні аналізаторні системи - оптичний, просторовий, соматопросторовий, мовноруховий та ін., то мозковою основою обчислень $є$ спільна робота потиличних, тім'яних і лобових систем мозку яку ми будемо називати системою зон мозку, які забезпечують обчислювальну діяльність (Цветкова Л. C., 1997, с.20).

При локальних ураженнях мозку неминучі різноманітні форми порушення функції лічби, що може виявитися при дефекті будь-якої з ланок його структури, причому форма розпаду залежить від того, який з елементів структури страждає. Тому порушення в обчисленнях можливе при ураженні майже будь-якої ділянки мозку (Цветкова Л. С., 1997).

Важливим є положення, запропоноване Л. Виготським, яке полягає в тому, що функціональне значення певної ділянки кори головного мозку є неоднаковим на різних етапах розвитку індивіда (Выготский Л. С., 1960, с. 36). Відповідно пошкодження певної ділянки мозку в ранньому дитинстві системно впливає на більш високі зони кори мозку. Проте пошкодження тієї ж області вже у зрілому віці впливає на нижчі зони кори, які від них залежать. Це одне з фундаментальних положень про динамічну локалізацію вищих психічних функцій (Лурия А. Р., 2003, с. 79-80).

у нейропсихології динамічною локалізацією називаються робочі об'єднання різних зон і рівнів мозку, що забезпечують ту або іншу психічну функцію і можуть змінюватися в міру її формування, тобто функція змінюється 
з розвитком людини за своєю структурою. Відбуваються зміни й у ї̈ взаємозв'язках із іншими психічними процесами, а отже, змінюється її локалізація, яка різко відрізняється в дитини і дорослого (Цветкова Л. С., Семенович А.В., Котягина С.Н., Гришина Е.Г., \&Гогберашвили Т.Ю., 2006, с. 71-72).

\section{ВИСНОВКИ ТА ПЕРСПЕКТИВИ ПОДАЛЬШИХ ДОСЛІДЖЕНЬ}

Як бачимо, про вузьку локалізацію в функціональній системі можна говорити тільки щодо окремих її елементів. Повноцінна обчислювальна діяльність забезпечується роботою низки об'єднаних зон головного мозку. Нейропсихологічні дослідження про системну локалізацію обчислювальної діяльності як одного з видів вищих психічних функцій дає можливість визначити підхід до аналізу їх порушень та можливостей і шляхів їх виявлення й відновлення.

\section{СПИСОК ВИКОРИСТАНИХ ДЖЕРЕЛ}

Выготский, Л. С. (1960) Развитие высших психических функций. М.: АПН РСФСР.

Выготский, Л. С. (1983) Собрание сочинений: В б-ти т. Т.З. Проблемы развития психіки. М.: Педагогика.

Гальперин, П. Я. (2002) Лекции по психологии: Учебное пособие для студентов вузов. М: Книжный дом «Университет»: Высшая школа.

Давыдов, В. В. (2003) Новый подход к пониманию структуры и содержания деятельности. Вопр. психологии, 2, $42-49$.

Лурия, А. Р. (2003) Основы нейропсихологии. Учеб. пособие для студ. высш. учеб. заведений. М.: Издательский центр «Академия».

Лурия, А. Р. К паталогии счетых операцій. Вопросы педагогической психологи. Труды научно-исследовательского институ-та психологии. Москва - Лениград, 181-207.

Медіна Джон (2017) Правила розвитку мозку дитини (пер.з анг. Рибчак Т.). 3-тє вид. К.: Наш формат.

Менчинская, Н. А. (2004) Проблемы обучения, воспитания и психического развития ребенка: Избранные психологические труды. М.: Издательство Московского психолого-социального института; Воронеж: Издательство НПО «МОД.ЭК».

Непомнящая, Н. И. (2001) Психодиагностика личности: Теория и практика: Учеб. пособие для студ. высш. учеб. заведений. М.: Гуманит. изд. центр ВЛАДОС.

Пиаже, Ж. (1969) Избранные психологические труды. М. : Просвещение.

Рубинштейн, С. Л. (2002) Основы общей психологии. Издательство: Питер.

Цветкова, Л. С. (1995) Мозг и интеллект: Нарушение и восстановление интеллектуальной деятельности. М.: Просвещение АО «Учеб. лит.».

Цветкова, Л. С. (2000) Введение в нейропсихологію и восстановительное обучение. Учебное пособие. М.: Московский психолого-социальный институт.

Цветкова, Л. С. (1997) Нейропсихология счета, письма и чтения: нарушение и восстановление. М.: «Юристь».

Цветкова, Л. С., Семенович, А.В., Котягина, С.Н., Гришина, Е.Г., \&Гогберашвили Т.Ю. (2006) Актуальные проблемы нейропсихологии детского возраста: учеб.пособие. М.: Издательство Московского психолого-социального института; Воронеж: Изда-тельство НПО «МОДЭК».

Юнг, К. Г. (2008) Структура и динамика психического. М.: «Когито-Центр».

\section{REFERENCES}

Vygotskiy, L. S. (1960) Razvitiye vysshikh psikhicheskikh funktsiy. M.: APN RSFSR.

Vygotskiy, L. S. (1983) Sobraniye sochineniy: V b-ti t. T.Z. Problemy razvitiya psikhнki. M.: Pedagogika.

Gal'perin, P. Ya. (2002) Lektsii po psikhologii: Uchebnoye posobiye dlya studentov vuzov. M: Knizhnyy dom «Universitet»: Vysshaya shkola.

Davydov, V. V. (2003) Novyy podkhod k ponimaniyu struktury i soderzhaniya deyatel'nosti. Vopr. psikhologii, 2, 42-49.

Luriya, A. R (2003). Osnovy neyropsikhologii. Ucheb. posobiye dlya stud. vyssh. ucheb. Zavedeniy. M.: Izdatel'skiy tsentr «Akademiya».

Luriya, A. R. K patalogii schetykh operatshy. Voprosy pedagogicheskoy psikhologii. Trudy nauchno-issledovatel'skogo instituta psikhologii. Moskva - Lenigrad, 181-207.

Medina Dzhon (2017) Pravyla rozvytku mozku dytyny (Rybchak T., Trans). 3-tye vyd. K.: Nash format.

Menchinskaya, N. A. (2004) Problemy obucheniya, vospitaniya i psikhicheskogo razvitiya rebenka: Izbrannyye psikhologicheskiye trudy. M.: Izdatelstvo Moskovskogo psikhologo-sotsial'nogo instituta; Voronezh: Izdatel'stvo NPO «MOD.EK.

Nepomnyashchaya, N. I (2001). Psikhodiagnostika lichnosti: Teoriya i praktika: Ucheb. posobiye dlya stud. vyssh. ucheb. zavedeniy. M.: Gumanit. izd. tsentr VLADOS.

Piazhe, Zh. (1969) Izbrannyye psikhologicheskiye trudy. M. : Prosveshcheniye.

Rubinshteyn, S. L. (2002) Osnovy obshchey psikhologii. Izdatel'stvo: Piter.

Tsvetkova, L. S. (1995) Mozg i intellekt: Narusheniye i vosstanovleniye intellektual'noy deyatel'nosti. M.: Prosveshcheniye - AO «Ucheb. lit.».

Tsvetkova, L. S. (2000) Vvedeniye v neyropsikhologнуи i vosstanovitel'noye obucheniye. Uchebnoye posobiye. M.: Moskovskiy psikhologo sotsial'nyy institute.

Tsvetkova, L. S. (1997) Neyropsikhologiya scheta, pis'ma i chteniya: narusheniye i vosstanovleniye. M.: «Yurist».

Tsvetkova, L. S., Semenovich, A. V., Kotyagina, S. N., Grishina, Ye. G., \&Gogberashvili T.Yu. (2006) Aktual'nyye problemy neyropsikhologii detskogo vozrasta: ucheb.posobiye. M.: Izdatel'stvo Moskovskogo psikhologo-sotsial'nogo instituta; Voronezh: Izdatel'stvo NPO «MODEK».

Yung, K. G. (2008) Struktura i dinamika psikhicheskogo. M.: «Kogito-Tsentr.

Статтю подано до редколегії 15.04 .2019 p.

Рекомендовано до друку $\quad$ 06.05.2019 p. 